\title{
-
}

Jurnal Kepariwisataan | P-ISSN 1412-5498 | E-ISSN 2581-1053 Vol. 20 No. 1 - Maret 2021

DOI: https://doi.org/10.52352/jpar.v20i1.449 Publisher: P3M Politeknik Pariwisata Bali Available online: https:// .ppb.ac.id/index.php/jpar

\section{PERSEPSI WISATAWAN TERHADAP KUALITAS DESTINASI PARIWISATA BALI}

\author{
Hanugerah Kristiono Liestiandre \\ Program Studi Manajemen Kepariwisataan, Politeknik Pariwisata Bali \\ Jl. Dharmawangsa Kampial, Nusa Dua Bali \\ andre.hanoo@gmail.com
}

\author{
\begin{tabular}{l|l|l} 
Received: June, 2021 & Accepted: June, 2021 & Published: July, 2021
\end{tabular}
}

\begin{abstract}
One of the strategic efforts in maintaining customer satisfaction and loyalty can be done by maintaining service quality. Service quality can be defined as the level of guest or consumer satisfaction. The level of guest satisfaction is obtained from the comparison of real services received by visitors, with the previously expected quality values. This research will explore the extent of tourists' perceptions of the quality of Bali destinations. The respondents who will provide information in this study are tourists who meet the requirements as respondents to be able to fill in and provide the information needed when filling out the questionnaire. There were 200 respondents with a composition of 200 domestic tourists and 100 foreign tourists. The analysis technique used in this study was measured using the Customer Satisfaction Index (CSI) and Importance Performance Analysis (IPA) methods. The results showed that domestic tourists and foreign tourists have different levels of satisfaction and performance appraisals. As a recommendation, the result of this study could be considered as an evaluation of the quality of tourism destinations in Bali.
\end{abstract}

Keywords: tourist perceptions, destination quality, tourism destinations

\begin{abstract}
Abstrak
Salah satu upaya strategik dalam menjaga kepuasan dan loyalitas pelanggan dapat dilakukan dengan cara menjaga kualitas pelayanan. Kualitas pelayanan dapat diartikan sebagai tingkat kepuasan tamu atau konsumen. Tingkat kepuasan tamu diperoleh dari perbandingan pelayanan yang nyata diterima pengunjung, dengan nilai kualitas yang sebelumnya diharapkan. Penelitian ini bertujuan untuk menggali sejauh mana persepsi wisatawan terhadap kualitas destinasi Bali. Responden yang memberikan informasi dalam penelitian ini adalah wisatawan yang memenuhi persyaratan sebagai responden untuk dapat mengisi dan memberikan informasi yang dibutuhkan saat pengisiaan kuesioner. Jumlah responden sebanyak 200 orang dengan komposisi 100 wisatawan domestik dan 100 orang wisatawan mancanegara. Teknik analisis yang digunakan dalam penelitian ini diukur dengan menggunakan metode Customer Satisfaction Index (CSI) dan Importance Performance Analysis (IPA). Hasil penelitian menunjukkan bahwa wisatawan nusantara dan wisatawan mancanegara memiliki tingkat kepuasan dan penilaian kinerja yang berbeda. Hasil penelitian ini dapat digunakan sebagai bahan pertimbangan dan evaluasi mengenai
\end{abstract}


kualitas destinasi atau daya tarik wisata yang telah dikembangkan oleh masing-masing wilayah di Bali.

Kata Kunci: persepsi wisatawan, kualitas destinasi, destinasi pariwisata

\section{PENDAHULUAN}

Pada awal tahun 2020 ini, sebuah pandemi yang menimpa dunia telah memberikan suatu perubahan yang besar bagi dunia, khususnya pariwisata. Pandemi ini telah memberi dampak yang besar terhadap seluruh aspek kehidupan manusia. Seluruh sektor industri pun mengalami perubahan yang besar sejak awal tahun 2020 ini, hingga diperkirakan beberapa tahun ke depan. Akibat dari pandemi ini, protokol kesehatan telah menjadi prioritas dan perhatian dunia agar penyebaran atau penularan virus ini dapat diminimalkan. Aktivitas manusia seolah-olah dibatasi dan dipaksakan untuk mengikuti suatu perilaku yang baru dari dari sebelumnya (next normal), seperti selalu menjaga jarak antar manusia (physical distancing), selalu menggunakan masker, selalu mencuci tangan, dan selalu menjaga kesehatan tubuhnya. Pada bulan April 2020, 91\% dari seluruh umat manusia dilarang untuk bepergian dan tinggal di rumah, serta melarang seseorang untuk masuk ke suatu negara atau daerah yang bukan merupakan daerah tempat tinggalnya (Wen, et.al, 2020). Demikian pula isu ini telah menjadi ketakutan dan kekuatiran seseorang (Aguilera, 2020; Fang, 2020), khususnya dalam pola konsumsinya (Hall, et.al., 2020). Banyaknya informasi yang beredar diberbagai media yang belum pasti kebenarannya berdampak pada seseorang yang kuatir untuk keluar rumah termasuk melakukan perjalanan wisata.

Dampaknya yang lain, pandemi ini juga telah memengaruhi motivasi dan perilaku manusia dalam melakukan perjalanan wisata. Covid-19 kemungkinan akan memengaruhi pola konsumsi wisatawan, seperti semakin populernya perjalanan bebas dan mandiri, perjalanan mewah. dan pariwisata kesehatan. Bentuk-bentuk baru pariwisata termasuk pariwisata lambat (slow tourism) dan pariwisata cerdas (smart tourism) juga dapat mendorong kegiatan pariwisata di masa depan. Perubahan seperti itu kemungkinan akan memaksa bisnis pariwisata untuk mempertimbangkan kembali desain layanan dan saluran distribusinya (Wen et al, 2020). Bahkan pandemi ini juga telah berdampak yang cukup signifikan terhadap hal-hak seseorang untuk turut mengambil bagian dalam sektor pariwisata dan hospotaliti dari beberapa negara dari sebelumhya (Baum dan Hai, 2020). Pandemi covid-19 menunjukkan bahwa baik industri jasa maupun komunitas penelitian layanan menghadapi suatu kenyataan baru, sesuatu yang tidak siap untuk ditangani. Kerangka kerja baru diperlukan untuk memahami dampak wabah virus tersebut, dan konsep pemasaran layanan saat ini perlu diteliti kembali dari perspektif baru (Kabadayi, 2020, dalam Wen, et.al, 2020), khususnya dalam pengelolaan destinasi pariwisata, bahkan peran perilaku prediksi wisatawan secara fundamental sangat penting dalam menilai kinerja perencana dan pemasar layanan pariwisata di masa depan. Ini juga akan sangat membantu keberhasilan pengembangan sektor pariwisata, dan memiliki nilai praktis untuk semua pemangku kepentingan pariwisata (Gharibi, 2020).

Kepuasan adalah kondisi atau bentuk yang dimiliki seseorang mengalami layanan yang telah memenuhi kebutuhannya pada di waktu titik tertentu. Kepuasan adalah konstruk kumulatif yang terpengaruh oleh harapan layanan dan persepsi kinerja di setiap periode dan dipengaruhi oleh kepuasan masa lalu dari periode ke periode. Kualitas layanan dianggap sebagai inti dan titik fokus untuk manajemen bandara, sebagai bandara di 
dunia terus mengadopsi bisnis yang berorientasi strategi pasar (Adeniran and Fadare, 2018).

Daya saing destinasi pariwisata (Destination Competitiveness) menurut Buhalis (2000) hendaknya memiliki beberapa komponen agar dapat bersaing dengan destinasi pariwisata internasional yang terdiri dari 6As, yaitu Attractions (natural, man-made, artificial, purpose built, heritage, special events), Accessibility (entire transportation system comprising of routes, terminals and vehicles), Amenities (accommodation and catering facilities, retailing, other tourist services), Available packages (prearranged packages by intermediaries and principals), Activities (all activities available at the destination and what consumers will do during their visit), Ancillary services (services used by tourists such as banks, telecommunications, post, newsagents, hospitals, etc.). Mengelola dan memasarkan destinasi pariwisata juga menantang karena berbagai pemangku kepentingan yang terlibat dalam pengembangan dan penciptaan produk pariwisata. Pengalaman destinasi pariwisata dalam mengelola dan memasarkannya pada dasarnya terdiri dari luasan daerah, sumber daya, dan campuran fasilitas dan layanan pariwisata, yang sering tidak dimilik secara individu. Sebaliknya mewakili kepentingan kumpulan profesional dan pribadi semua orang yang tinggal dan bekerja di daerah tersebut. Mengelola destinasi pariwisata sering bertentangan dengan kepentingan para pemangku kepentingan dalam mengendalikan dan memasarkan destinasi pariwisata secara keseluruhan. Karena itu, strategi dan tindakan harus dilakukan memperhitungkan keinginan semua pemangku kepentingan, yaitu masyarakat adat, bisnis dan investor, wisatawan, operator tur dan perantara, serta kelompok yang berkepentingan. Masalah yang paling sulit adalah memastikan penggunaan rasional barang publik yang tak ternilai, seperti bentang alam, gunung, dan laut untuk keuntungan semua pemangku kepentingan dan pada saat yang sama melestarikan sumber-sumber untuk generasi mendatang.

Destinasi pariwisata agar dapat memiliki daya saing yang unggul dan berkelanjutan dapat menggunakan teori Resource-Based View (RBV) yang lebih melihat sisi dalam dari faktor internal yaitu kekuatan atau kelemahan. RBV adalah pendekatan untuk mencapai keunggulan kompetitif yang muncul pada tahun 1980-an dan 1990-an, setelah karya besar yang diterbitkan oleh Wernerfelt, (1984), Prahalad dan Hamel (1990), dan Barney (1991). Pandangan ini berpendapat bahwa organisasi harus melihat ke dalam perusahaan untuk menemukan sumber keunggulan kompetitif. Barney (1991) telah mengidentifikasi kerangka kerja VRIN yang meneliti apakah sumber daya tersebut berharga (Valuable), langka (Rare), mahal untuk ditiru (Imperfectly Imitable), dan tidak dapat disubstitusikan (non-Substitutability). Kerangka kerja ini kemudian ditingkatkan dari VRIN ke VRIO, menjadi pertanyaan-pertanyaan yang harus dijawab terhadap Nilai sumber daya (Value), Kelangkaan sumber daya dan kemampuan (Rarity), kemungkinan untuk ditiru (Imitability), dan ekspolitasi potensi sumberdaya serta kemampuan oleh organisasi (Organization).

Pengelola destinasi pariwisata atau Destination Management Organization (DMO) disarankan untuk fokus kondisi terhadap lingkungan destinasi pariwisatanya yang lebih luas daripada infrastruktur dan bisnis yang telah miliki lebih banyak kontrol langsung. Kualitas dan nilai yang dimiliki sebuah destinasi pariwisata, keduanya memiliki pengaruh kuat pada persepsi wisatawan, yang pada gilirannya mempengaruhi penilaian mereka terhadap daya saing suatu destinasi pariwisata, sehingga mereka akan kembali pada destinasi tersebut (Wang dkk, 2017; Shahijan, et.al., 2018). Pengelola destinasi pariwisata perlu 
mempertimbangkan dan memasukkan faktor-faktor ini ke dalam strategi perencanaan keseluruhannya, termasuk perencanaan fisik dan sosial, bersama dengan kemitraan yang lebih kuat dengan masalah bisnis.

Masalah kualitas telah menjadi subjek banyak peneliti pariwisata saat ini. Para peneliti percaya tujuan yang harus terpenuhi bagi harapan wisatawan dan membedakan diri dari pesaing adalah melalui kualitas (Limberger, et.al., 2014). Terdapat beberapa faktor yang menjadi perhatian dalam mengukur kualitas destinasi parawisata, yaitu Coretourism experience, Culture, Information centers, Personal information, Hospitality, Fairness of price, Hygiene, Distractions, Value for money, Amenities, Pubs, Logistics, Security, dan Food (Narayan, et.al., 2008). Wisatawan semakin menuntut sehubungan dengan kualitas produk dan layanan yang ditawarkan selama mereka berada di destinasi pariwisata (Anjos, et.al., 2017). Kualitas destinasi pariwisata terdiri dari tiga utama komponen yaitu kualitas infrastruktur, kualitas sumber daya manusia, serta kualitas lingkungan dan alam. Kualitas infrastruktur (infrastructure quality) terdiri atas infrastruktur transportasi darat dan udara, serta teknologi komunikasi informasi. Indikator kualitas sumber daya manusia (human resource quality) adalah sistem pendidikan, ketersediaan untuk layanan penelitian dan pelatihan khusus lokal, tingkat pelatihan staf, ketersediaan tenaga kerja yang berkualitas, kemudahan merekrut tenaga kerja asing, dan sikap populasi terhadap pengunjung asing. Komponen terakhir dari kualitas destinasi pariwisata adalah kualitas alam dan lingkungan (natural and environmental quality) yang terdiri dari jumlah situs alami warisan dunia, kualitas lingkungan alam, total spesies yang diketahui, jumlah situs budaya warisan dunia, akses ke sanitasi yang lebih baik, akses untuk air minum yang lebih baik, ketatnya regulasi lingkungan, keberlanjutan industri perjalanan dan pariwisata, spesies yang terancam, ratifikasi perjanjian lingkungan, dan emisi karbon dioksida (Assaf dan Tsionas, 2015).

Kualitas destinasi pariwisata berkaitan juga dengan kepuasan atau ketidakpuasan wisatawan. Dalam hal ini, terdapat model tujuan wisata berdasarkan 6 (enam) kelompok variabel terkait dengan kepuasan dan 2 (dua) kelompok variabel yang berhubungan dengan ketidakpuasan. Kelompok-kelompok ini terdiri dari unsur-unsur berikut; Kelompok Kepuasan 1 yang terdiri dari produk matahari dan pantai, Kelompok Kepuasan 2 terdiri dari kegiatan budaya dan kontak dengan alam, Kelompok Kepuasan 3 terdiri dari kegiatan dan interaksi sosial, Kelompok Kepuasan 4 terdiri dari aksesibilitas dan pilihan, Kelompok Kepuasan 5 terdiri dari gaya hidup lokal, dan Kelompok Kepuasan 6 yaitu harga. Sedangkan yang berhubungan dengan ketidakpuasan yaitu Kelompok Ketidakpuasan 1 yang terdiri dari pengembangan berlebihan dan kemacetan lalu lintas, dan Kelompok Ketidakpuasan 2 yaitu kinerja buruk (Alegre \& Garau, 2010). Ketika destinasi pariwisata dapat memberikan kualitas yang baik maka dapat meningkatkan kepuasan bagi wisatawan dan minat bagi wisatwan untuk berkunjung, terutama wisatawan mancanegara (Rajaratnam, et.al., 2015). Untuk dapat mengukur tingkat kinerja dan harapan dari kualitas sebuah destinasi pariwisata, pengukuran tersebut akan menggunakan 10 dimensi terkait keberhasilan sebuah destinasi (Morisson, 2013), dimana setiap dimensi tersebut memiliki indikator-indikator yang akan dinilai dan penilaiannya akan menggunakan skala likert. 10 dimensi tersebut adalah:

1) Kesadaran (Awareness). Unsur ini berkaitan dengan tingkat pengetahuan wisatawan tentang destinasi yang dipengaruhi oleh banyaknya serta jenis informasi yang mereka terima. Apakah tingkat pengetahuan tentang destinasi itu 
cukup tinggi di antara wisatawan yang potensial?

2) Daya pikat (Attractiveness). Beberapa daya pikat destinasi secara geografis yang menonjol merupakan hal yang penting dalam hal ini. Apakah destinasi yang bersangkutan menawarkan daya pikat yang beragam dan menonjol bagi wisatawan?

3) Ketersediaan (Availability). Unsur ini ditentukan oleh kemudahan memperolehnya seperti booking atau pemesanannya, - baik cara maupun jumlah jaringannya. Dapatkah booking atau pemesanannya dilakukan melalui jaringan distribusi yang beragam?

4) Akses (Access). Unsur ini menyangkut kenyamanan untuk mencapai destinasi tersebut, begitu juga untuk bepergian di dalam destinasi itu. Apakah bepergian ke/dari serta di dalam destinasi itu nyaman dilakukan dengan semua jenis angkutan?

5) Apresiasi (Appreciation). Tingkat penyambutan yang menyenangkan bagi wisatawan sebagai "tamu" yang dirasakan sebagai keramahan adalah yang dimaksud dalam apresiasi ini. Apakah Wisatawan merasa "disambut" dan mendapat layanan yang baik di dalam destinasi tersebut?

6) Jaminan (Assurance). Unsur ini berkaitan dengan keselamatan dan keamanan bagi pribadi wisatawan dan barang bawaannya selama di destinasi yang bersangkutan. Apakah destinasi itu bersih, terjamin keselamatannya (safe) dan keamanannya (secure)?

7) Aktivitas (Activities). Luasnya pilihan susunan daftar kegiatan yang tersedia bagi wisatawan merupakan hal yang menentukan daya pikat destinasi. Apakah destinasi menawarkan pilihan kegiatan yang cukup luas bagi wisatawan untuk ikut terlibat?
8) Penampilan (Appearance). Unsur penampilan ini terkait dengan kesan yang dirasakan wisatawan dari destinasi yang bersangkutan baik pada saat tiba maupun sepanjang ia tinggal di destinasi itu. Apakah destinasi memberikan kesan pertama yang baik? Apakah destinasi tersebut memberikan kesan baik dan bertahan lama kepada wisatawan?

9) Tindakan (Action). Keberadaan Rencana Jangka Panjang Pariwisata dalam hal pembinaan / pengembangan serta pemasarannya merupakan beberapa tindakan yang dibutuhkan. Apakah pengembangan Kepariwisataan dan Pemasarannya direncanakan dengan baik?

10) Akuntabilitas (Accountability). Unsur ini menyangkut evaluasi kinerja DMO. Apakah DMO mencatat dan menilai efektivitas kinerjanya?

Untuk meningkatkan kunjungan wisatawan tersebut, banyak pengelola destinasi pariwisata memainkan atribut destinasinya ke dalam aktivitas pemasaran. Diharapkan melalui destinasi pariwisata yang berkualitas (destination quality) dengan meningkatkan citra destinasi pariwisata (detination image) sebagai atribut destinasi pariwisata yang unggul (destination competitiveness) dapat meningkatkan dan memainkan peran penting dalam mendatangkan wisatawan. Selain melalui aktivitas pemasaran, atribut sebuah destinasi juga akan mempengaruhi kualitas dari destinasi pariwisata tersebut, yang akhirnya akan mempengaruhi minat seseorang untuk berkunjung ke destinasi pariwisata (Moon dan Han, 2018). Jika pengelola desinasi pariwisata dapat mengkombinasikan seluruh atribut destinasi yang dimilikinya akan dapat meningkatkan minat pada seseorang (Ekanayake \& Gnanapala, 2016; Eusébio \& Vieira, 2013; Kim \& Brown, 2012; Sangpikul, 2018). Atribut destinasi menjadi hal yang penting dalam menarik wisatawan untuk berkunjung, baik wisatawan yang berasal dari Barat maupun wisatawan yang berasal dari 
Asia (Reisinger, et.al., 2009). Pengelola destinasi pariwisata, berupaya mengoptimalkan atribut destinasi yang dimilikinya, juga untuk membangun citra destinasi yang layak dikunjungi

\section{METODE PENELITIAN}

Teknik analisis yang digunakan dalam Kepuasan pelanggan dapat diukur dengan menggunakan metode Customer Satisfaction Index (CSI) dan Importance Performance Analysis (IPA). CSI adalah metode pengukuran untuk mengetahui tingkat kepuasan pelanggan secara menyeluruh dengan mempertimbangkan tingkat kepentingan dari atribut-atribut kualitas pelayanan jasa yang diukur (Syukri, 2014). Sedangkan IPA bertujuan untuk mengukur hubungan antara persepsi konsumen dan prioritas peningkatan kualitas produk/jasa (Dirgantara \& Sambodo, 2014). Analisis IPA merupakan suatu metode analisis yang merupakan kombinasi antara aspek-aspek tingkat kepentingan dan persepsi terhadap kualitas atau kondisi suatu objek ke dalam bentuk dua dimensi. Tahapan dalam analisis penelitian ini pertama melakukan pembobotan, uji validitas dan realibilitas, serta analisis CSI dan IPA,

Adapun responden yang akan memberikan informasi dalam penelitian ini yaitu wisatawan yang memenuhi persyaratan sebagai responden untuk dapat mengisi dan memberikan informasi yang dibutuhkan saat pengisiaan kuesioner, yaitu wisatawan yang telah dan sedang berkunjung ke Bali. Jumlah responden sebanyak 200 orang dengan komposisi 100 wisatawan domestik dan 100 orang wisatawan mancanegara, dengan penyebaran kuisioner melalui pendekatan online.

Berdasarkan uji validitas dan reabilitas diketahui bahwa indikator dinyatakan valid dan reliable dengan nilai Cronbach's Alpha 0,914 dan 0,937 untuk tingkat kepentingan dan kinerja.

\section{HASIL DAN PEMBAHASAN \\ 3.1 Deskripsi Data}

Adapun jumlah sampel pada responden wisatawan nusantara yakni berjumlah total 100 responden. Persentase jenis kelamin untuk profil responden wisatawan nusantara ialah didominasi oleh kaum perempuan dengan jumlah persentase sebesar $61,3 \%$ yang dibandingkan dengan persentase pada kaum laki-laki sebesar $38,7 \%$. Didominasi ialah pada rentang usia 17-25 tahun dengan jumlah persentase yakni $82,1 \%$. Sedangkan usia 26-35 mendominasi kedua yakni sebesar $16 \%$. Jenis pekerjaan sebagai mahasiswa/pelajar dengan total persentase $68,9 \%$ dan pegawai swasta dengan frekuensi 19,8\%. Dimana dalam hal ini didominasi oleh wisatawan Nusantara yakni sebanyak 2 kali dalam kurun waktu 5 tahun terakhir, dengan persentase $33 \%$, sedangkan yang kedua didominasi mengunjungi Bali sebanyak $>4$ kali dengan persentase 27,4\%. mereka yang merencanakan perjalanannya bersama keluarga atau teman atau saudara, dengan total persentase sebanyak 77,4\%. Kemudian kedua didominasi bersama dengan sekolah/universitas sebanyak 14,2\%, dan yang mendapatkan informasi dari keluarga atau teman yakni dengan persentase sebesar 49,1\%. Kemudia yang kedua didominasi berdasarkan sumber informasi internet atau media elektronik yakni sebesar $43,4 \%$.

Jenis kelamin untuk profil responden wisatawan mancanegara ialah didominasi oleh laki-laki dengan jumlah persentase sebesar $57,4 \%$ yang dibandingkan dengan persentase pada perempuan sebesar 42,6\%. Terdiri dari empat kelompok rentang usia, yakni usia 17-25 tahun, 26-35 tahun, 36-45 tahun, dan <45 tahun. Pada wisatawan mancanegara yang mendominasi ialah pada rentang usia 26-35 tahun dengan persentase yakni $38 \%$. Sedangkan kelompok usia yang kedua didominasi pada rentang usia 17-25 tahun yakni 
sebesar $28,7 \%$. Jenis pekerjaan sebagai pengusaha (entreprenuer) dengan persentase $19,4 \%$. Dan professional dan pelajar yakni $17,6 \%$. Tingkat penghasilan tiap bulannya yaitu $\$ 1,201-\$ 3,500$, dengan persentase $27,8 \%$ dan penghasilan lebih rendah ialah pada rata-rata pengahasilan tiap bulannya sebesar <US\$1,200 dan >US\$10,000 persentase yang sama yaitu 10,2\%. Rentang rata-rata seberapa banyak wisatawan mancanegara telah mengunjungi Balididominasi oleh wisatawan yakni sebanyak 2 kali dalam kurun waktu 5 tahun dengan total persentase $25 \%$, sedangkan yang kedua didominasi mengunjungi Bali sebanyak 3 kali dengan persentase 24,1\%. Wisatawan yang merencanakan perjalanannya bersama keluarga atau teman atau saudara, dengan persentase sebanyak $52,8 \%$ dan bersama dengan diri sendiri sebanyak 24,1\%. Sedangkan sumber informasi dari keluarga atau teman yakni dengan total persentase sebesar $50 \%$ daninternet atau media elektronik yakni sebesar 28,7\%.

\subsection{Pembahasan}

Tingkat kesesuaian antara harapan dan persepsi wisatawan nusantara untuk

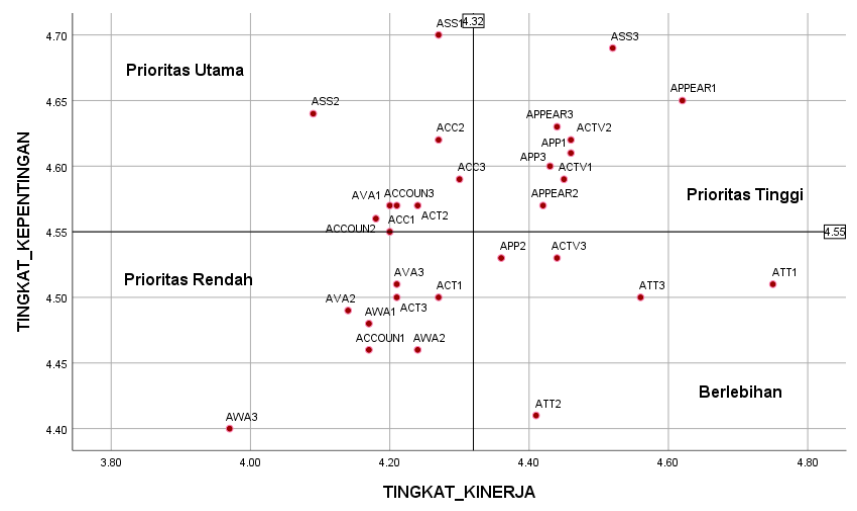

Gambar 1. Analisis Kuadran Wisatawan Nusantara
Berdasarkan gambar di atas, maka faktor-faktor yang berkaitan dengan kualitas destinasi yang dimiliki oleh Bali, maka dapat dikelompokan ke dalam masing-masing kuadran sebagai berikut: 1) Kuadran A (Prioritas Utama) kualitas destinasi Bali menunjukkan skor penilaian total yakni pada persentase $95.91 \%$. Dalam hal tingkat kesuaian dapat dikatakan sangat baik. Hasil analisis rata-rata analisis kesenjangannya (GAP) untuk semua dimensi kualitas destinasi Bali sebesar 2.32. Hal ini menunjukkan bahwa wisatawan merasa belum/kurang puas dengan pelayanan yang belum sesuai/mendekati apa yang mereka harapkan. Sehingga dalam hal ini dapat diartikan bahwa semakin besar skor kesenjangan, maka indikator tersebut semakin diprioritaskan untuk diperbaiki oleh pihak manajemen destinasi pariwisata. Berdasarkan nilai CSI ditemukan sebesar $42.39 \%$, yang berarti wisatawan merasa kurang puas terhadap kinerja kualitas destinasi yang dimiliki oleh Bali.

Berdasarkan pemetaan indikator disetiap kuadran beserta nilai rataratanya, kemudian hasil perhitungan nilai rata-rata tingkat kepuasan dan ratarata tingkat kinerja untuk setiap kuadran, maka hasil perhitungan ini ditampilkan pada Gambar 1.
Kuadran A menjelaskan kinerja yang miliki Bali rendah sebagai sebuah destinasi, namun tingkat harapan wisatawan Nusantara tinggi. Adapun indikator-indikator yang terdapat di dalam Kuadran A tersebut dianggap penting oleh wisatawan Nusantara tetapi 
pada kenyataannya hal-hal tersebut belum sesuai dengan harapan wisatawan Nusantara.

Oleh karena itu, pihak manajemen perlu atau memberikan prioritas utama untuk mengalokasikan sumber dayanya guna meningkatkan performa yang masuk pada kuadran ini. Adapun urutan prioritas perbaikannya adalah pada indikator sebagai berikut:

- (Ava 1) Informasi mengenai aktivitas wisatawan dan atraksi wisata

- (Acc 1) Kenyamanan akses untuk menuju atraksi wisata (selama perjalanan wisata)

- (Acc 2) Kenyamana akses menuju Bali

- (Acc 3) Kenyamanan dari aksesibilitas di daya tarik wisata

- (Ass 1) Kualitas keamanan Bali

- (Ass 2) Kualitas sanitasi dan hygiene.

- (Act 2) Pengelolaan dari pariwisata Bali

- (Accoun2) Ketanggapan (kesigapan) dari Manajemen Organisasi Destinasi terhadap Pariwisata Bali

- (Accoun 3) Kewajiban (tanggung jawab) dari Manajemen Organisasi Destinasi terhadap Pariwisata Bali

Dilihat dari beberapa komentar wisatawan nusantara yang telah menjadi responden, terkait pelaksanaan beberapa indikator yang digolongkan pada kuadran A, pertama yaitu pada indikator Ava 1, beberapa wisatawan nusantara merasakan adanya ketidaknyamanan dalam pemberian informasi dari Bali sebagai destinasi mengenai aktivitas wisatawan dan atraksi wisata yang lengkap dan membantu dalam menunjang kegiatan wisata mereka di Bali, padahal hal tersebut sangatlah wisatawan nusantara butuhkan karena diharapkan mampu mempermudah wisatawan nusantara dalam melakukan kegiatan wisata di Bali.

Selanjutnya, pada indikator Acc 1, 2 dan 3 mengenai aksesibilitas pada Bali sebagai destinasi, dimana wisatawan nusantara merasakan adanya ketidaknyamanan atas aksesibilitas, khususnya kondisi jalan raya yang mengalami kemacetan yang berlebih, hal tersebut juga mampu meningkatkan polusi udara akibat asap kendaraan. Pariwisata di Bali diharapkan mampu membenahi kualitasnya sehingga tidak menjadi 'mass tourism' yang dikhawatirkan mampu merusak lingkungan, terutama dari segi kenyamanan aksesibilitas wisatawan nusantara saat melakukan perjalanan di Bali sebagai destinasi.

Pada indikator Ass 1 dan 2 terkait dengan keamanan dan kebersihan /sanitasi, dapat dilihat bahwa sangat disayangkan Bali sebgaai destinasi yang sudah begitu mendunia menjadi rentan akan kekerasan atau perampokan. Selain itu, dari segia sanitasi dilihat dari fasilitas wisata yang ada pada sebagian besar daya tarik masih dirasa kurang oleh wisatawan nusantara dalam hal perawatan dan pemeliharaan kebersihan, sehingga dianggap berbanding terbalik dengan popularitas Bali yang kini sudah menjadi salah stau destinasi dunia.

Kemudian pada indikator Act 2 terkait pengelolaan Bali sebagai destinasi, wisatawan nusantara masih merasakan adanya ketidaknyamanan, khususnya dalam pengelolaan tata ruang sektor pariwisata di Bali sebagai destinasi. Yang terakhir ialah pada indikator account 2 dan 3 mengenai kinerja pengelola destiasi dinilai masih tergolong kurang berperan aktifoleh wisatawan nusantara, sehingga wisatawan nusantara masih mengaharapkan adanya keterlibatan yang lebih tanggap dan bertanggung jawab dari DMO terkait mengenai pengelolaan Bali sebagai destinasi. Dengan demikian, item-item tersebut diatas menjadi skala prioritas utama Bali destinasi untuk diperbaiki atau dibenahi. 2) Kuadran B (Prioritas Tinggi)

Kuadran B menjelaskan kinerja yang miliki Bali tinggi sebagai sebuah destinasi dan tingkat harapan wisatawan Nusantara tinggi. Adapun indikatorindikator yang terdapat di dalam 
Kuadran B tersebut dianggap sangat penting oleh wisatawan dan hasilnya sangat memuaskan. Hal-hal ini memiliki kinerja yang tinggi dan wajib dipertahankan untuk waktu selanjutnya.

Oleh karena itu, adapun urutan prioritas indikator yang manajemen wajib untuk mempertahankan prestasi kinerja tersebut, sebagai berikut:

- (App 1) Keramah-tamahan pelayanan di setiap fasilitas wisata

- (App 3) Keramah-tamahan dan keperdulian dari masyarakat lokal Bali

- (Ass 3) Kenyamanan Bali sebagai destinasi pariwisata

- (Actv 1) Keberagaman aktivitas wisata

- (Actv 3) Keunikan dari aktivitas wisata

- (Appear 1) Kesan pertama terhadap Bali sebagai destinasi pariwisata

- (Appear 2) Kesan selama perjalanan wisata

- (Appear 3) Kesan setelah perjalanan wisata

Dilihat dari beberapa komentar wisatawan nusantara yang telah menjadi responden, terkait pelaksanaan beberapa indicator yang digolongkan pada kuadran A, pertama yaitu pada indikator App 1 dan 3 terkait sikap sosial yang diberikan masyarakat lokal Bali kepada wisatawan nusantara, beberapa wisatawan nusantara merasakan sifat kekeluargaan, keramah-tamahan yang diberikn oleh masyarakat lokal yang membuat wisatawan nyaman selama berwisata dan berinteraksi dengan masyarakat lokal di lingkungan daya tarik yang ada di bali sebagai destinasi, begitu pula pada indicator Ass 3 dikarenakan hal tersebut jugalah maka wisatawan nusantara merasakan adanya kenyamana saat berwisata di Bali sebagai destinasi.

Selanjutnya yaitu pada indicator Actv 1 dan 3 terkait keberagaman dan keunikan daya tarik wisata yang ada pada Bali sebagai destinasi dimana hal tersebut muncul karena adanya kekhasan Bali dalam hal kebudayaan serta kebiasaan yang hanya dapat dilihat dan dilakukan di Bali saja. Yang terakhir ialah pada indicator Appear 1, 2, dan 3 dimana Bali sebagai destinasu mampu memberikan daya tarik, aktivitas, maupun keunikan budaya bagi wisatawan nusantara yang telah berkujung ke Bali sehingga membuat mereka ingin kembali dan bahwa menjadi wisatawan 'repeater' atau wisatawan yang berkunjung ke Bali bahkan lebih dari 1 kali atau dalam kata lain mampu membuat wisatawan nusantara menjadi loyal untuk kembali berkunjung ke Bali sebagai destinasi. Dengan demikian, item-item tersebut diatas perlu dipertahankan kinerjanya oleh Bali sebagai destinasi.

3) Kuadran C (Prioritas Rendah)

Kuadran C menjelaskan kinerja yang miliki Bali rendah sebagai sebuah destinasi dan tingkat harapan wisatawan Nusantara rendah. Adapun indikatorindikator yang terdapat di dalam Kuadran C tersebut dianggap kurang penting oleh wisatawan dan kinerjanya juga dinilai kurang baik.

Oleh karena itu, manajemen tidak perlu memprioritaskan atau memberikan perhatian lebih pada faktorfaktor tersebut, namun lebih baik untuk ditingkatkan tidak untuk diabaikan. Adapun urutan prioritas indikator tersebut sebagai berikut:

- (Awa 1) Pengetahuan mengenai aktivitas wisata

- (Awa 2) Pengetahuan mengenai atraksi wisata (daya tarik wisata)

- (Awa 3) Pengetahuan mengenai fasilitas wisata

- (Ava 2) Informasi mengenai moda trasportasi

- (Ava 3) Informasi mengenai fasilitas wisata

- (Act 1) Sistem promosi pariwisata Bali

- (Act 3) Sistem tata ruang (design pengelolaan) pariwisata Bali 
- (Accoun 1) Kinerja dari Manajemen Organisasi Destinasi terhadap Pariwisata Bali

Dapat dilihat itu merupakan indicator yang masuk dalam kuadran $\mathrm{C}$ merupakan indicator yang dapat diperbaiki atau juga diabaikan akan tetapi jika itu diabaikan nantinya jika dalam pengembangan destinasi itu bias menjadi hal yang buruk jadi itu menandakan bahwa setiap indicator harus di benahi agar lebih baik lagi untuk Bali sebagai destinasi.

4) Kuadran D (Berlebihan)

Kuadran D menjelaskan kinerja yang miliki Bali tinggi sebagai sebuah destinasi, namun tingkat harapan wisatawan Nusantara rendah. Adapun indikator-indikator yang terdapat di dalam Kuadran D tersebut menunjukkan variabel yang memuaskan tetapi pelaksanaannya terlalu berlebihan dan dianggap kurang penting oleh konsumen.

Oleh karena itu, manajemen lebih baik mengalokasikan sumber daya yang terkait pada faktor tersebut kepada faktor lain yang lebih memiliki tingkat prioritas lebih tinggi. Adapun urutan indikator tersebut sebagai berikut:

- (Att 1) Keindahan dari potensi alam

- (Att 2) Keindahan dari atraksi wisata buatan

- (Att 3) Keindahan dari sosial-budaya

- (App 2) Keramah-tamahan dari pelayanan imigrasi
- (Actv 3) Keterlibatan masyarakat lokal dalam aktivitas wisata

Dari indikator itu kebanyakan merupakan dari atraksi wisata yang ada di Bali, menunjukan bahwa Bali terlalu berlebihan seperti atraksi wisata bali sudah memang bagus dan sudah pasti menjadi atraksi wisata memang penting serta dapat memuaskan wisatawan saat berkunjung, tidak hanya itu Bali juga sudah memang terkenal dengan keramah tamahannya dimata dunia terlebih juga pada masyarakat lokal.

Harapan dan Persepsi wisatawan mancanegara untuk kualitas destinasi Bali menunjukkan skor penilaian total yakni pada persentase $98.94 \%$. Dalam hal tingkat kesuaian dapat dikatakan sangat baik. Hasil analisis rata-rata GAP untuk semua dimensi kualitas destinasi Bali sebesar - 0.45. Hal ini menunjukkan bahwa wisatawan merasa belum/kurang puas dengan pelayanan yang belum sesuai/mendekati apa yang mereka harapkan. Sehingga dalam hal ini dapat diartikan bahwa semakin besar skor kesenjangan, maka indikator tersebut semakin diprioritaskan untuk diperbaiki oleh pihak manajemen destinasi pariwisata. Berdasarkan perhitungan, diketahui bahwa nilai CSI sebesar 87.31\% yang berarti wisatawan merasa sangat puas terhadap kinerja kualitas destinasi yang dimiliki oleh Bali.

Hasil analisis kuadran untuk data responden wisatawan mancanegara ditampilkan dalam Gambar 2.:

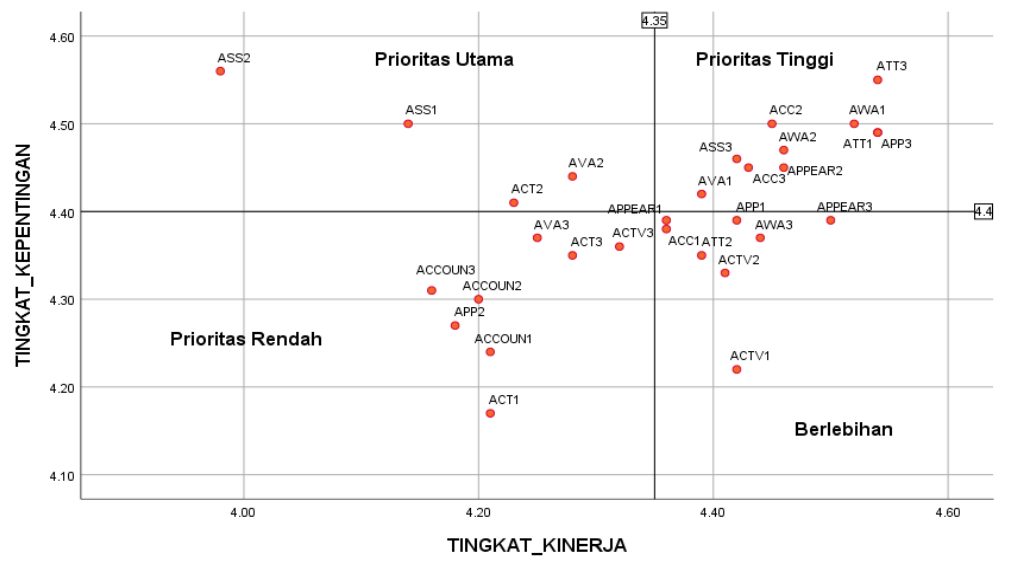

Gambar 2: Analisis Kuadran Wisatawan Mancanegar 
1) Kuadran A (Prioritas Utama)

Kuadran A menjelaskan kinerja yang miliki Bali rendah sebagai sebuah destinasi, namun tingkat harapan wisatawan Mancanegara tinggi. Adapun indikator-indikator yang terdapat di dalam Kuadran A tersebut dianggap penting oleh wisatawan Mancanegara tetapi pada kenyataannya hal-hal tersebut belum sesuai dengan harapan wisatawan Mancanegara.

Oleh karena itu, pihak manajemen perlu atau memberikan prioritas utama untuk mengalokasikan sumber dayanya guna meningkatkan performa yang masuk pada kuadran ini. Adapun urutan prioritas perbaikannya adalah pada indikator sebagai berikut:

- (Ava 2) The information about modes of transportation.

- (Ass 1) The safety quality of Bali.

- (Ass 2) The sanitation and hygiene quality.

- (Act 3) The tourism layout system of Bali as tourism destination.

Dilihat dari beberapa komentar wisatawan nusantara yang telah menjadi responden, terkait pelaksanaan beberapa indicator yang digolongkan pada kuadran A, pertama yaitu pada indicator Ava 2, rata-rata wisatawan mancanegara merasa sangat penting dalam pemberian informasi tentang moda transportasi di Bali yang dimana bagi wisatawan mancanegara sangatlah membutuhkan informasi mengenai moda transportasi ketika sedang ada di Bali.

Selanjutnya, pada indikator Ass 1 dan 2 terkait dengan keamanan dan kebersihan/sanitasi, dapat dilihat bahwa rata-rata wisatawan mancanegara menilai kebersihan dan keamanan di Bali ini masih kurang, disayangkan sekali padahal Bali sebagai destinasi yang sudah begitu mendunia menjadi rentan akan kekerasan atau perampokan. Selain itu, dari segi sanitasi dilihat dari fasilitas wisata yang ada pada sebagian besar daya tarik masih dirasa kurang oleh wisatawan mancanegara dalam hal perawatan dan pemeliharaan kebersihan, sehingga dianggap berbanding terbalik dengan popularitas Bali dimata wisatawan mancanegara dan Bali yang kini sudah menjadi salah satu destinasi dunia.

Selanjutnya yang terakhir pada indikator Act 3 terkait tata ruang pariwisata Bali sebagai tujuan wisata, wisatawan mancanegara sudah merasakan adanya kenyamanan, khususnya dalam pengelolaan tata ruang pariwisata di Bali sebagai tujuan wisata. Yang dimana penilaian wisatawan mancanegara sangatlah berbanding terbalik dengan penilaian wisatawan nusantara.

2) Kuadran B (Prioritas Tinggi)

Kuadran B menjelaskan kinerja yang miliki Bali tinggi sebagai sebuah destinasi dan tingkat harapan wisatawan Mancanegara tinggi. Adapun indikatorindikator yang terdapat di dalam Kuadran B tersebut dianggap sangat penting oleh wisatawan dan hasilnya sangat memuaskan. Hal-hal ini memiliki kinerja yang tinggi dan wajib dipertahankan untuk waktu selanjutnya.

Oleh karena itu, adapun urutan prioritas indikator yang manajemen wajib untuk mempertahankan prestasi kinerja tersebut sebagai berikut:

- (Awa 1) The knowledge about tourism activity.

- (Awa 2) The knowledge about tourism object.

- (Att 1) The beautifulness of nature resources.

- (Att 3) The beautifulness of socio cultural.

- (Ava 1) The information about tourist activities and tourist attraction.

- (Acc 2) The convenience of access to Bali.

- (Acc 3) The convenience of accessibility in tourism destination of Bali.

- (App 3) The hospitality and respectness of Bali's local community.

- (Ass 3) The convenience of Bali as tourism destination. 
- (Appear 2) The impression during trip in Bali.

Dilihat dari beberapa komentar wisatawan mancanegara yang telah menjadi responden, terkait pelaksanaan beberapa indicator yang digolongkan pada kuadran B, pertama yaitu pada indikator Awa 1 dan 2 terkait pengetahuan tentang aktivitas wisata dan obyek wisata yang dimana penilaian wisatawan mancangera rata-rata menilai sangat penting dikarenakan wisatawan mancanegara harus mengetahui aktivitas apa saja yang bisa dilakukan sebelum datang ke Bali dan obyek wisata mana saja yang bagus untuk dikunjungi ketika berada di Bali. Selanjutnya pada indikator Att 1 dan 3 tentang keindahan sumber daya alam dan keindahan social budaya yang Bali miliki, yang dimana sebagian wisatawan mancanegara merasa sangatlah penting bagi suatu destinasi memiliki keindahan sumber daya alam dan social budaya untuk menarik wisatawan datang ke Bali.

Selanjutnya pada indikator Ava 1 mengenai informasi tentang kegiatan wisata dan daya tarik wisata, dimana wisata mancanegara sangatlah membutuhkan informasi untuk kegiatan wisata dan daya tarik wisata yang ada di Bali agar wisatawan tidak merasa kecewa jika realita tidak sebagus ekspetasi yang wisatawan pikirkan. Selanjutnya pada indikator Acc 2 dan 3 mengenai kenyamanan akses ke bali dan kemudahan aksesibilitas ke tujuan wisata di Bali, yang dimana wisatawan mancanegara merasa sangat penting kenyamanan dan kemudahan akses jalan menuju suatu daya tarik wisata yang ingin wisatawan datangi. Namun, masih terdapat di beberapa daya tarik wisata yang memiliki akses jalan yang masih sangat kurang bagus.

Selanjutnya pada indikator App 3 mengenai keramahan dan rasa hormat dari komunitas lokal Bali, wisatawan merasa sangatlah penting bagi wisatawan untuk mendapatkan keramahan dari masyarakat sekitar dan bisa saling menghormati satu sama lain agar wisatawan mancanegara merasa nyaman ketika berkunjung ke suatu daya tarik wisata yang ada di Bali. Selanjutnya pada indikator Ass 3 mengenai kenyamanan bali sebagai tujuan wisata, wisatawan mancanegara rata-rata menilai bahwa sangatlah penting kenyamanan suatu destinasi untuk berwisata dengan tujuan untuk menghilangkan stress yang diakibatkan pekerjaan ataupun suasana perkotaan di negara asal mereka, yang dimana bagi wisatawan mancanegara bila sedang berwisata kenyamanan lah yang terpenting.

Kemudian yang terakhir pada indikator Appear 2 dimana Bali sebagai destinasi mampu memberikan kesan perjalanan daya tarik, aktivitas, maupun keunikan budaya bagi wisatawan mancanegara yang telah berkujung ke Bali sehingga membuat mereka ingin kembali dan bahwa menjadi wisatawan 'repeater' atau wisatawan yang berkunjung ke Bali bahkan lebih dari 1 kali atau dalam kata lain mampu membuat wisatawan mancanegara menjadi loyal untuk kembali berkunjung ke Bali sebagai destinasi. Dengan demikian, item-item tersebut diatas perlu dipertahankan kinerjanya oleh Bali sebagai destinasi.

3) Kuadran C (Prioritas Rendah)

Kuadran C menjelaskan kinerja yang miliki Bali rendah sebagai sebuah destinasi dan tingkat harapan wisatawan Mancanegara rendah. Adapun indikatorindikator yang terdapat di dalam Kuadran $\mathrm{C}$ tersebut dianggap kurang penting oleh wisatawan dan kinerjanya juga dinilai kurang baik.

Oleh karena itu, manajemen tidak perlu memprioritaskan atau memberikan perhatian lebih pada faktorfaktor tersebut, namun dapat sarankan lebih baik untuk ditingkatkan tidak untuk diabaikan. Adapun urutan prioritas indikator tersebut sebagai berikut:

- (Ava 3) The information about tourism aminities 
- (App 2) The hospitality of service at immigration

- (Actv 3) The involvement of local community on the tourism activities

- (Act 1) The tourism promotion system of Bali

- (Act 3) The tourism layout system of Bali as tourism destination

- (Accoun 1) The Destination Management Organization (DMO)'s performance of Bali as tourism destination

- (Accoun 2) The DMO's responsiveness of Bali as tourism destination

- (Accoun 3) The DMO's responsibility of Bali as tourism destination

Dapat dilihat itu merupakan indicator yang masuk dalam kuadran $\mathrm{C}$ merupakan indicator yang dapat diperbaiki atau juga diabaikan akan tetapi jika itu diabaikan nantinya jika dalam pengembangan destinasi itu bisa menjadi hal yang buruk jadi itu menandakan bahwa setiap indicator harus di benahi agar lebih baik lagi untuk Bali sebagai destinasi.

Dilihat dari beberapa komentar wisatawan mancanegara yang telah menjadi responden, terkait pelaksanaan beberapa indikator yang digolongkan pada kuadran C, pertama yaitu pada indikator Ava 3 Informasi mengenai fasilitas wisata, wisawatan mengatakan mereka membutuhkan itu dan sudah mudah untuk dijangkau dikarenakan tersedianya banyak moda transportasi yang ada di Bali baik online maupun offline yang sangat mudah untuk diakses. Pada App 2 yaitu terkait pelayanan di imigasi, khususnya pada Bandar Udara Internasional Ngurah Rai dimana persepsi wisatawan mengatakan bahwa harapan mereka rendah terhadap pelayanan pada imigrasi, serta menunjukkan kinerja yang masih rendah. Sebaiknya manajemen melakukan evaluasi kembali untuk program-program yang telah disusun sebagai SOP dalam melakukan pelayanan di imigrasi kepada wisatawan, sehingga hal ini dapat menjadi hal utama atau harapan yang tinggi bagi wisatawan.

Selain itu pada indikator Act 1 Sistem promosi pariwisata Bali sangatlah penting untuk dijalankan mengingat persaingan global dimana setiap Negara berusaha untuk memajukan pariwisata daerah mereka sehingga promosi untuk Bali harus bisa dijalankan dengan baik walaupun bali sudah terkenal tetapi seiring waktu dan perubahan-perubahan yang ada membutuhkan promosi yang sedemikian rupa sehingga wisatawan yang berkunjung kebali bisa tetap konsisten, Act 3 Sistem tata ruang (desain pengelolaan) pariwisata Bali seharusnya perlu sangat diperhatikan dikarenakan pengelolaan wisata di Bali sekarang ini dianggap kurai sesuai dan masih tidak tepat sasaran contohnya banyak penyelewengan keputusan serta terdapat banyak property bodong serta orang asing yang bekerja di Bali tanpa visa.

Kemudian untuk Accoun 1 Kinerja dari Manajemen Organisasi Destinasi terhadap Pariwisata Bali ini yang harus diperhatikan mengingat banyak bencana yang terjadi serta pademi akhir-akhir ini mengharuskan manajemen organisasi yang ada di Bali harus bekerja dengan baik sehingga pariwisata dibali bisa kembali normal. Selain itu, dapat dijelaskan bahwa indikator Accoun 2 dan Accoun 3 yang sama-sama merupakan indikator dari akuntabilitas menunjukkan bahwa, harapan wisatawan rendah terhadap pengelolaan destinasi Bali, dimana kinerja nya pun rendah. Oleh karena itu, pada variabel ini dengan melihat 3 indikator utama yakni terkait ada kinerja, ketanggapan, dan tanggung jawab DMO terhadap destinasi Bali perlu untuk ditingkatkan, dan sangat disarankan untuk ditidak diabaikan oleh manajemen. Apabila 3 indikator ini dapat ditingkatkan, kemungkinan adanya peluang harapan yang baik dari wisatawan mancanegara.

4) Kuadran D (Berlebihan)

Kuadran D menjelaskan kinerja yang miliki Bali tinggi sebagai sebuah 
destinasi, namun tingkat harapan wisatawan mancanegara rendah. Adapun indikator-indikator yang terdapat di dalam Kuadran D tersebut menunjukkan variabel yang memuaskan tetapi pelaksanaannya terlalu berlebihan dan dianggap kurang penting oleh konsumen.

Oleh karena itu, manajemen lebih baik mengalokasikan sumber daya yang terkait pada faktor tersebut kepada faktor lain yang lebih memiliki tingkat prioritas lebih tinggi. Adapun urutan indikator tersebut sebagai berikut:

- (Awa 3) The knowledge about tourism amenities

- (Att 2) The beautifulness of manmade acttraction

- (Acc 1) The convenience of access to get the tourism destination (during trip)

- (App 1) The hospitality of service at each tourism aminities

- (Actv 1) The diversity of tourism activities

- (Actv 2) The uniqness of tourism activities

- (Appear 1) The first impression of Bali as tourism destination

- (Appear 3) The impression after trip in Bali

Dari indikator itu kebanyakan merupakan dari atraksi wisata yang ada di Bali, menunjukan bahwa Bali terlalu berlebihan seperti atraksi wisata bali sudah memang bagus dan sudah pasti menjadi atraksi wisata memang penting serta dapat memuaskan wisatawan saat berkunjung, tidak hanya itu Bali juga sudah memang terkenal dengan keramah tamahannya dimata dunia terlebih juga pada masyarakar lokal.

Dilihat dari beberapa komentar wisatawan mancanegara yang telah menjadi responden, terkait pelaksanaan beberapa indikator yang digolongkan pada kuadran D indikator (Awa 3) The knowledge about tourism amenities, dimana hal ini dikarenakan tingkat kesadaran wisatawan terkait pengetahuan fasilitas wisata di Bali, dapat mudah diketahui pada zaman ini.
Dimana hal ini didukung dengan teknologi dan informasi yang telah memungkinkan. Sehingga, persepsi wisatawan mengatakan bahwa indikator ini teralalu berlebihan dari upaya kinerja yang telah dilakukan baik pemerintah maupun, pemangku kepentingan pariwisata yang terlibat didalamnya. Selanjutnya apabila dilihat dari indikator (Att 2) The beautifulness of manmade acttraction, hal ini dianggap berlebihan oleh wisatawan mancanegara dikarenakan upaya promosi ataupun pengembangan yang dilakukan, dimana persepsi mereka yang seharusnya mengarah kepada nature atau culture Bali sebagai destinasi.

Indikator selanjutnya ialah pada (Acc 1) The convenience of access to get the tourism destination (during trip) yang merupakan variabel akses. Dimana hal ini dianggap berlebihan dalam hal kinerjanya dilihat dari akses jalan yang memadai yang diimbangi dengan moda transportasi yang dapat digunakan. Pada indikator (App 1) The hospitality of service at each tourism aminities, dikatakan berlebihan menurut wisatawan mancanegara dimana hal ini masih belum terlalu berlebihan bagi beberapa akomodasi yang menerapkan kinerja hosipitaliti, namun hal ini hanya berlaku bagi beberapa wisatawan. Selanjutnya dilihat dari (Actv 1) The diversity of tourism activities dan (Actv 2) The uniqness of tourism activities, dimana merupakan variabel aktivitas. Dalam hal ini, menurut wisatawan mancanegara hal ini berlebihan dikarenakan keberangaman aktivitas wisata dan keunikannya masih belum dimaksimalkan dengan baik. Kemudian dilihat dari indikator (Appear 1) The first impression of Bali as tourism destination dan (Appear 3) The impression after trip in Bali, yang merupakan variabel penampilan. Dimana hal ini dilihat dari ekspetasi kesan pertama dan kesan selama liburan yang dirasakan wisatawan tidak sesuai dengan harapan, sehingga dianggap berlebihan dalam kinerja destinasi Bali itu sendiri. 


\section{KESIMPULAN}

Berdasarkan dari hasil riset pemasaran pariwisata yang telah dilakukan mengenai Persepsi Wisatawan Terhadap Kualitas Destinasi Bali, maka dapat diambil kesimpulan dengan berdasarkan atas dua persepsi hasil penelitian yakni persepsi wisatawan nusantara dan wisatawan mancanegara, bagi wisatawan nusantara yaitu:

1) Berdasarkan tingkat kesesuaian (Kinerja dan Kepentingan), yang dilihat dari indikator-indikator yang digunakan melalui perbandingan kinerja dan kepentingan, memperoleh total $95.91 \%$ (sangat baik) yakni; mulai dari indikator kesadaran, daya tarik, ketersediaan, akses, apresiasi, jaminan, aktivitas, penampilan, tindakan, dan akuntibilitas.

2) Berdasarkan analisis kesenjangan (GAP), analisis yang diperoleh ialah dengan nilai skor kesenjangan yang besar terkait kinerja dan harapan yang diinginkan oleh wisatawan Nusantara terhadap Bali sebagai destinasi pariwisata, berarti kinerja masih jauh dari harapan wisatawan.

3) Berdasarkan CSI (Customer Satisfaction Index) menunjukkan wisatawan nusantara kurang puas atas kinerja yang diberikan Bali sebagai destinasi pariwisata terhadap harapan wisatawan nusantara yang datang ke Bali untuk menghabiskan waktu luangnya. Hal ini yang dikarenakan lebih banyaknya GAP negatif yang masih belum memenuhi harapan wisatawan, berdasarkan ukuran daripada indikator yang digunakan.

4) Berdasarkan diagram kartesius, masih adanya indikator yang kurang sesuai dengan harapan, bahkan dinilai berlebihan.

Sementara itu, persepsi wisatawan mancanegara yaitu:

1) Berdasarkan tingkat kesesuaian (Kinerja dan Kepentingan), memperoleh total $98.94 \%$ (sangat baik) yakni; mulai dari indikator Awareness, Attractiveness, Availability, Access, Appreciation, Assurance, Activities, Appearance, Action, dan Accountibility

2) Berdasarkan analisis kesenjangan (GAP), menunjukkan bahwa GAP antara kinerja yang diberikan Bali sebagai destinasi pariwisata terhadap dan harapan wisatawan mancanegara tidak terlalu besar dibandingkan dengan GAP wisatawan nusantara.

3) Berdasarkan CSI (Customer Satisfaction Index), menunjukkan secara keseluruhan wisatawan mancanegara sangat puas atas kinerja yang diberikan Bali sebagai destinasi pariwisata terhadap harapan wisatawan mancanegara yang datang ke Bali untuk menghabiskan waktu luangnya.

4) Masih terdapat indikator yang kurang sesuai dengan harapan, bahkan dinilai berlebihan, yang kebanyakan merupakan indikator pada atraksi wisata yang ada di Bali.

\section{PERNYATAAN PENGHARGAAN}

Peneliti berterima kasih atas dukungan dari Politeknik Pariwisata Bali baik berupa moril maupun materiil. Demikian ucapan terima kasih disampaikan kepada mahasiswa Program Studi Manajemen Kepariwisataan Angkatan 2017 yang telah terlibat banyak dalam pengumpulan data dan pengolahan data.

\section{DAFTAR PUSTAKA}

Adeniran \& Fadare. (2018). Assessment of Passengers' Satisfaction and Service Quality in Murtala Muhammed Airport (MMA2), Lagos, Nigeria: Application of SERVQUAL Model. Journal of Hotel \& Business Management. 7(2)

Aguilera. (2020). Xenophobia 'Is a PreExisting Condition', How Harmful Stereotypes and Racism are Spreading Around The Coronavirus. TIME Health 2019-NCOV. 
Anjos, et.al. (2017). Quality attributes of Jericoacoara, Brazil. International Journal of Tourism Cities, 3(2) 196204

Alegre, J., \& Garau, J. (2010). Tourist Satisfaction and Dissatisfaction. Annals of Tourism Research, Vol. 37. No. 1, 52-73

Assaf, A. G., Tsionas, E. G. (2015). Incorporating Destination Quality Into The Measurement of Tourism Performance A Bayesian Approach. Tourism Management, Vol. 49, 58-71

Barney, J. (1991). Firm Resources and Sustained Competitive Advantage. Journal of Management, 17(1), 99120.

Baum, T. and Hai, N.T.T. (2020). Hospitality, Tourism, Human Rights and The Impact of Covid-19. International Journal of Contemporary Hospitality Management. 32(7) 2397-2407

Buhalis, D. (2000). Marketing the Competitive Destination of The Future, Tourism Management, 21(1) 97-116.

Chen, X., Cheng, Z., \& Kim, G.-B. (2020). Make It Memorable: Tourism Experience, Fun, Recommendation and Revisit Intentions of Chinese Outbound Tourists. Sustainability. 12(5).

Dirgantara, H. B., \& Sambodo, A. T. (2014). Penerapan Model Importance Performance Analysis dalam Studi Kasus: Analisis Kepuasan Konsumen bhinneka.com. Jurnal Sains dan Teknologi, 52-62.

Ekanayake, I. E., \& Gnanapala, A. C. (2016). Travel Experiences and Behavioural Intentions of The Tourists: A Study on Eastern Provinceofo Sri Lanka. Tourism, Leisure and Global Change 3(1) 50 61.

Eusébio, C., \& Vieira, A. L. (2013). Destination Attributes' Evaluation, Satisfaction and Behavioural Intentions: A Structural Modelling Approach. International Journal of Tourism Research, 15(1)66-80.
Fang, W.T. (2020). Tourism in Emerging Economies. Singapore: Springer.

Gharibi, N. (2020). The Evolution of Predictive Models and Tourism. Journal of Tourism Futures. https://doi.org/10.1108/JTF-042020-0046.

Hall, et.al. (2020). Pandemics, Transformations and Tourism: Be Careful What You Wish For. Tourism Geographies, 1-22.

Kim, A.K., Brown, G. (2012). Understanding the Relationships Between Perceived Travel Experiences, Overall Satisfaction, And Destination Loyalty. Anatolia An International Journal of Tourism and Hospitality Research, Vol. 23, No. 3. 328-347.

Limberger, P. F., Anjos, F. A., Meira, J. V. S. and Anjos, S. J. G. (2014). Satisfaction in Hospitality on Tripadvisor.Com: An Analysis of The Correlation Between Evaluation Criteria and Overall Satisfaction. Tourism and Management Studies, 10(01), pp.5965.

Moon, H., \& Han, H. (2018). Destination Attributes Influencing Chinese Travelers' Perceptions of Experience Quality and Intentions for Island Tourism: A Case of Jeju Island. Tourism Management Perspectives 28(1) 71-82.

Morrison, A. (2013). Marketing and Managing Tourism Destination. Routledge.

Narayan, et.al. (2020). Has tourism influenced Indonesia's current account?. Economic Analysis and Policy, Volume 69.

Prahalad, C. K. \& Hamel, G. (1990). The Core Competence of the Corporation. University of Illinois at Urbana-Champaign's Academy for Entrepreneurial Leadership Historical Research Reference in Entrepreneurship

Rajaratnam, et.al. (2015). Destination Quality and Tourists' Behavioural Intentions: Rural Tourist Destinations in Malaysia. Worldwide 
Liestiandre

Hospitality and Tourism Themes, Vol. 7, No. 5, 463-472.

Reisinger, et.al. (2009). The Importance of Destination Attributes: Western and Asian Visitors. Anatolia Anatolia an International Journal of Tourism and Hospitality Research, 20(1) 236253.

Sangpikul, A. (2018). The effects of travel experience dimensions on tourist satisfaction and destination loyalty: the case of an island destination. International Journal of Culture, Tourism and Hospitality Research, Vol. 12 No. 1, pp. 106-123. https://doi.org/10.1108/IJCTHR06-2017-0067

Shahijan, et.al. (2018). Qualities of Effective Cruise Marketing Strategy: Cruisers' Experience, Service Convenience, Values, Satisfaction and Revisit Intention. International Journal of Quality \& Reliability Management, Vol. 36 No. 10. pp. 2304-2327

Syukri, S. H. A. (2014). Penerapan Customer Satisfaction Index (CSI) dan Analisis Gap Pada Kualitas Pelayanan Trans Jogja. Jurnal Ilmiah Teknik Industri. Vol. 13, No.2. ISSN: 1412-6869.

Wang, T. L., Tran, P. T. K., Tran, V. T. (2017). Destination Perceived Quality, Tourist Satisfaction and Word-Of-Mouth. Tourism Review, Vol. 72, No. 4, pp. 392-410.

Wernerfelt, Birger. (1984). A ResourceBased View of the Firm. Strategic Management Journal, Vol. 5, No. 2. 171-180

Wen, et.al. (2020). Covid-19: Potential Effects on Chinese Citizens' Lifestyle and Travel. Tourism Review. Emerald Publishing Limited

https://www.pewresearch.org/facttank/2020/08/13/the-u-s-budgetdeficit-is-rising-amid-covid-19-butpublic-concern-about-it-is-falling/ diakses agustus 2020 